\title{
Applicability of Dimedone Assays for the Development of Online Aldehyde Sensor in Seawater Flooding Systems
}

\author{
Mohammed A. Al-Moniee1* ${ }^{*}$, Cees Koopal2, Naim Akmal'1, Sjaak van Veen², Xiangyang Zhu' ${ }^{1}$, \\ Peter F. Sanders' ${ }^{1}$, Fahad N. Al-Abeedi ${ }^{1}$, Ayman M. Amer ${ }^{1}$
}

${ }^{1}$ Saudi Arabian Oil Company (Saudi Aramco), Dhahran, KSA

${ }^{2}$ TNO (Netherlands Organization for Applied Scientific Research), Zeist, The Netherlands

Email: *mohammed.moniee@aramco.com

How to cite this paper: Al-Moniee, M.A., Koopal, C., Akmal, N., van Veen, S., Zhu, X.Y., Sanders, P.F., Al-Abeedi, F.N. and Amer, A.M. (2016) Applicability of Dimedone Assays for the Development of Online Aldehyde Sensor in Seawater Flooding Systems. Journal of Sensor Technology, 6, 101109.

http://dx.doi.org/10.4236/jst.2016.64008

Received: September 26, 2016

Accepted: October 21, 2016

Published: October 24, 2016

Copyright $\odot 2016$ by authors and Scientific Research Publishing Inc. This work is licensed under the Creative Commons Attribution International License (CC BY 4.0).

http://creativecommons.org/licenses/by/4.0/ (c) (i) Open Access

\begin{abstract}
Biocides are oilfield chemicals that are widely used to control bacterial activity throughout the oil industry. A feasibility study has been explored to develop detection techniques for biocide batch treatments, preferably on-line and in real-time, for their potential use in seawater flooding system. Several methods to measure key components of the biocide formulation were investigated and reported in previous study [1]. The enzymatic activity of an immobilized acetylcholine esterase (AChE) on the column material was successfully inhibited by some model compounds, but not by the actual biocides commonly used in Saudi Aramco seawater flooding system. In this paper, an alternative assay for biocide detection in the Saudi Aramco seawater flooding system was investigated for its applicability for the development of on-line biocide sensor. The assay was based on the detection of aldehyde functionality in the biocide mixture through measurement of a fluorescent derivative formed in the reaction of aldehyde groups and dimedone in the presence of ammonium acetate. The reaction of aldehyde groups with dimedone was demonstrated in seawater matrix, and the formed fluorescent product was successfully measured. The results showed that the dimedone-based assay was very sensitive, and relatively straightforward to perform. The ruggedness test also indicated that the assay is sensitive to minor changes of various specific conditions of the method. It is concluded that the dimedone assay is suitable for further development of a real-time biocide monitoring system to detect the presence of biocide slugs in seawater flooding system. The development of an automated on-line biocide sensor based on dimedone assay is underway.
\end{abstract}

\section{Keywords}

DNA Staining, Automated Monitoring, Autonomous Microbe Sensor, 
Microbial Sensor Prototype, Injection Seawater

\section{Introduction}

The seawater flooding system in Saudi Aramco is by far the largest of its kind in the world. Seawater is filtered, deoxygenated, treated with various organic biocides mixtures, and injected at strategic points along the periphery of the oil reservoir, displacing the oil and "pushing" it toward oil supply wells in the center of the formation for enhanced crude oil recovery. Biocides are used to control bacterial activity throughout the extensive seawater flooding network. The short duration, high concentration batch biocide treatment is designed to prevent the growth of bacteria in the system [2] [3], thereby minimizing biofouling and water quality deterioration before injecting into the formation.

Because the system's matrix size is huge, it is very challenging to detect the arrival of a biocide slug at the remote water injection wells. Furthermore, quantification of biocide residual concentration in "real time" at remote desert locations is not currently possible. This calls for the need to develop sensor technologies, which will quantify biocide residual concentrations hundreds of kilometers from the biocide injection location without manual sample collection and conventional wet chemistry analysis.

The ultimate objective of this work is to introduce a mechanism to detect the arrival of the biocide slug at the remote water injection wells, and to determine the concentration of the biocide residual in the range of $20-2000 \mathrm{ppm}$. Several techniques were explored during the feasibility study as basis for the development of biocide sensor [1]. The principles were to monitor changes in temperature (calorimetric), $\mathrm{pH}$, and/or chromophore concentration (colorimetric). Acetylcholine esterase (AChE) enzyme converts substrate acetylthiocholine to a product detectable at UV-VIS spectra, but its catalytic activity may be inhibited in the presence of the other compounds such as biocides. The principle of AChE inhibition has been widely used as biological sensing element in the fabrication of monitors [4]-[7]. In our previous study [1], the activity of immobilized AChE was successfully inhibited by model compounds acetylcholine and benzyl dimethyl decylammonium chloride, but the actual biocides commonly used in Saudi Aramco seawater flooding system failed show any significant inhibition of the enzyme. Therefore, the principle of AChE inhibition was determined to be not appropriate for on-line or on-site detection of relevant biocide ingredients used in Saudi Aramco.

As the biocide mixtures were mainly based on aldehyde functions (formaldehyde and glutaraldehyde), an alternative detection principle based on these functions was investigated in this paper for its applicability in Saudi Aramco seawater flooding system. A thorough literature review [8] identified a method which might be easily adapted to the needs and boundary conditions of the on-line biocide sensor. The method is based on the detection of a fluorescent product formed from dimedone (methone, CAS 126-81- 
8) reaction with aldehyde groups. The assay can be used to analyze aldehyde groups in general, i.e. it is sensitive to any aldehyde functions in the sample.

\section{Experimental Setup}

\subsection{Materials and Equipment}

Dimedone, ammonium acetate and other chemicals were purchased from Sigma-Aldrich and were used as received. All solutions were made with demineralized water. Reported $\mathrm{pH}$ values were measured with a WTW pH $538 \mathrm{pH}$ meter. Fluorescence measurements were performed with a Jasco fp-1520 fluorescence detector (Jasco Benelux). The vessels incorporation the coils for heating and cooling were homemade.

The dimedone assay was examined in the laboratory for its applicability in real-time biocide monitoring in the seawater matrix.

\subsection{Assay Principle}

The detection of aldehydes is based on the Hantzsch reaction (Figure 1) [9]-[11]. The aldehydes react with dimedone in the presence of ammonium acetate $\left(\mathrm{NH}_{4} \mathrm{Ac}\right)$ to form a fluorescent derivative [10]. This derivative has an excitation wavelength of $395 \mathrm{~nm}$ and an emission wavelength of $463 \mathrm{~nm}$. The reaction is fairly slow at room temperature, but highly accelerated at temperatures higher than $90^{\circ} \mathrm{C}$.

\subsection{Experimental Conditions}

The schematic setup of the dimedone assay is illustrated in Figure 2, and the experimental conditions are outlined in Table 1 .

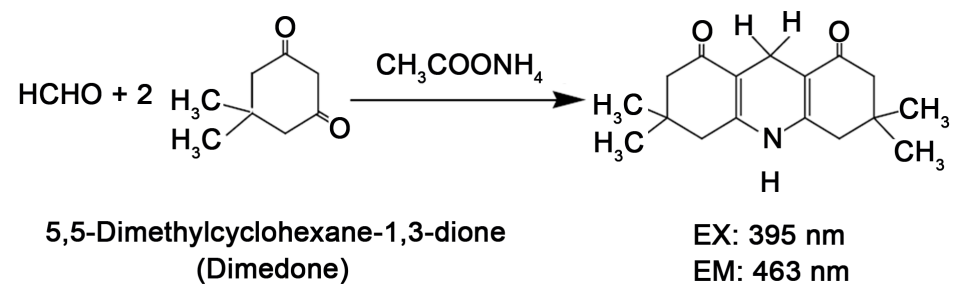

Figure 1. Hantzsch reaction scheme [10].

Table 1. Experimental conditions for dimedone assay.

Carrier solution

Reagent solution

Flow rate carrier solution

Flow rate reagent solution

Injection volume

Reaction coil

Detector
Distilled water

Dimedone, $\mathrm{NH}_{4} \mathrm{Ac}$ in distilled water at $\mathrm{pH} 4.5$

$$
\begin{gathered}
1 \mathrm{ml} / \mathrm{min} \\
0.5 \mathrm{ml} / \mathrm{min} \\
5 \mu \mathrm{l} \\
100^{\circ} \mathrm{C}
\end{gathered}
$$

Excitation $390 \mathrm{~nm}$

Emission $460 \mathrm{~nm}$ 


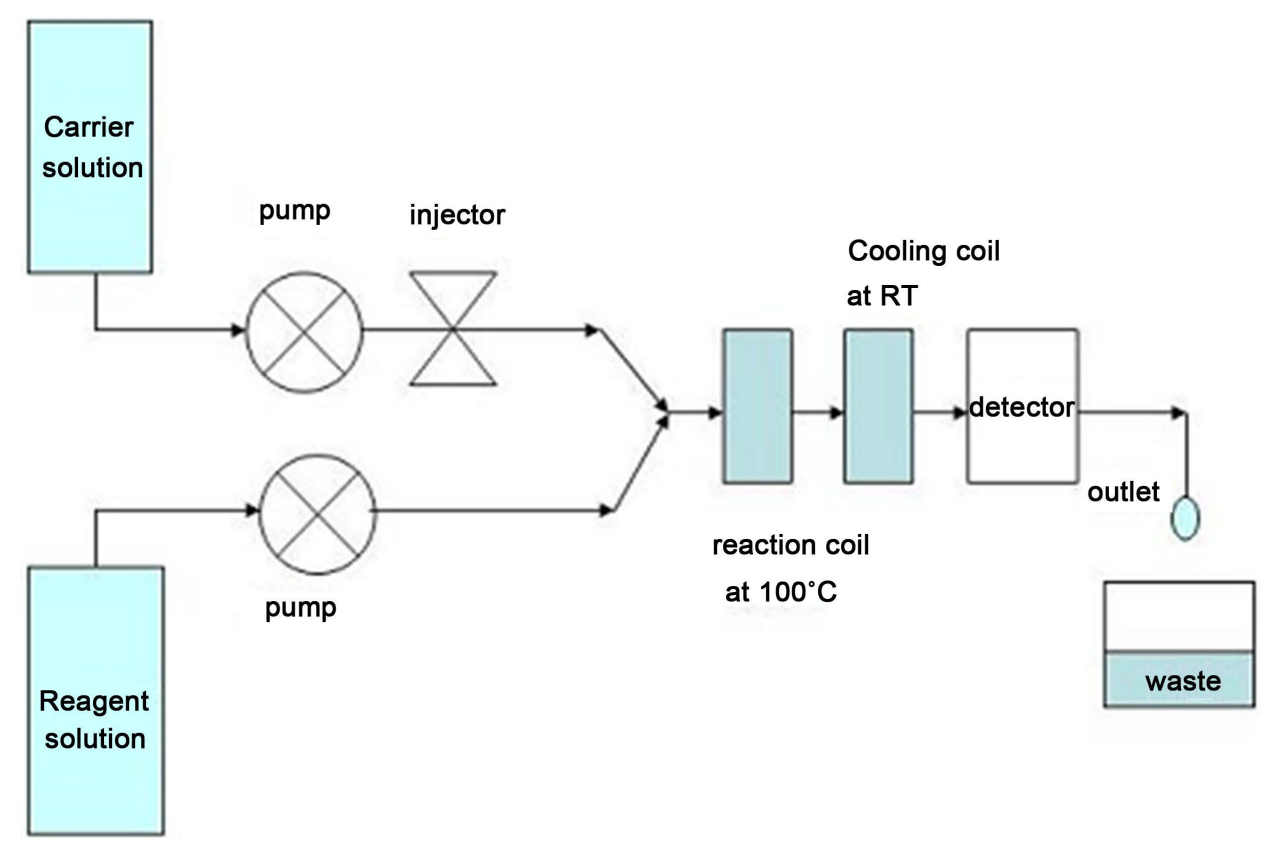

Figure 2. Schematic setup of the dimedone assay.

\subsection{Measurement Method}

The injection loop is filled with the aldehyde-containing sample (seawater with biocide). The sample is injected into the carrier flow. The carrier flow is mixed with the reagent flow and heated to $100^{\circ} \mathrm{C}$. After heating the reagent mixture is cooled to room temperature to prevent any boiling in the detector. The amount of dimedone derivative is measured at an emission wavelength of $460 \mathrm{~nm}$.

\section{Results and Discussion}

\subsection{Measurements of Aldehyde Functionality in Seawater Containing Biocide}

In the dimedone-based assay, this reagent reacts with the aldehyde group in a biocide formulation in the presence of ammonium acetate at $\mathrm{pH} 4.5$ and at an increased temperature (e.g. $100^{\circ} \mathrm{C}$ ), and forms a fluorescent complex. $500 \mathrm{ppm}$ of biocide A was reacted with dimedone for $30 \mathrm{~min}$ at $100^{\circ} \mathrm{C}$, and the fluorescent derivative was measured at emission wavelength of $460 \mathrm{~nm}$. The peak of the emission spectra showed that this fluorescent assay was very sensitive to the aldehyde function group present in the biocide (Figure 3).

Based on these promising results, the assay was further optimized in order to provide calibration curves for biocides A-D in seawater matrix.

\subsection{Determination of Aldehydes in a Flow Injection System with Dimedone Assay}

The calibration experiments were performed in seawater with various concentrations of biocide formulations indicated by A-D. The results of fluorescent signal from the reac- 

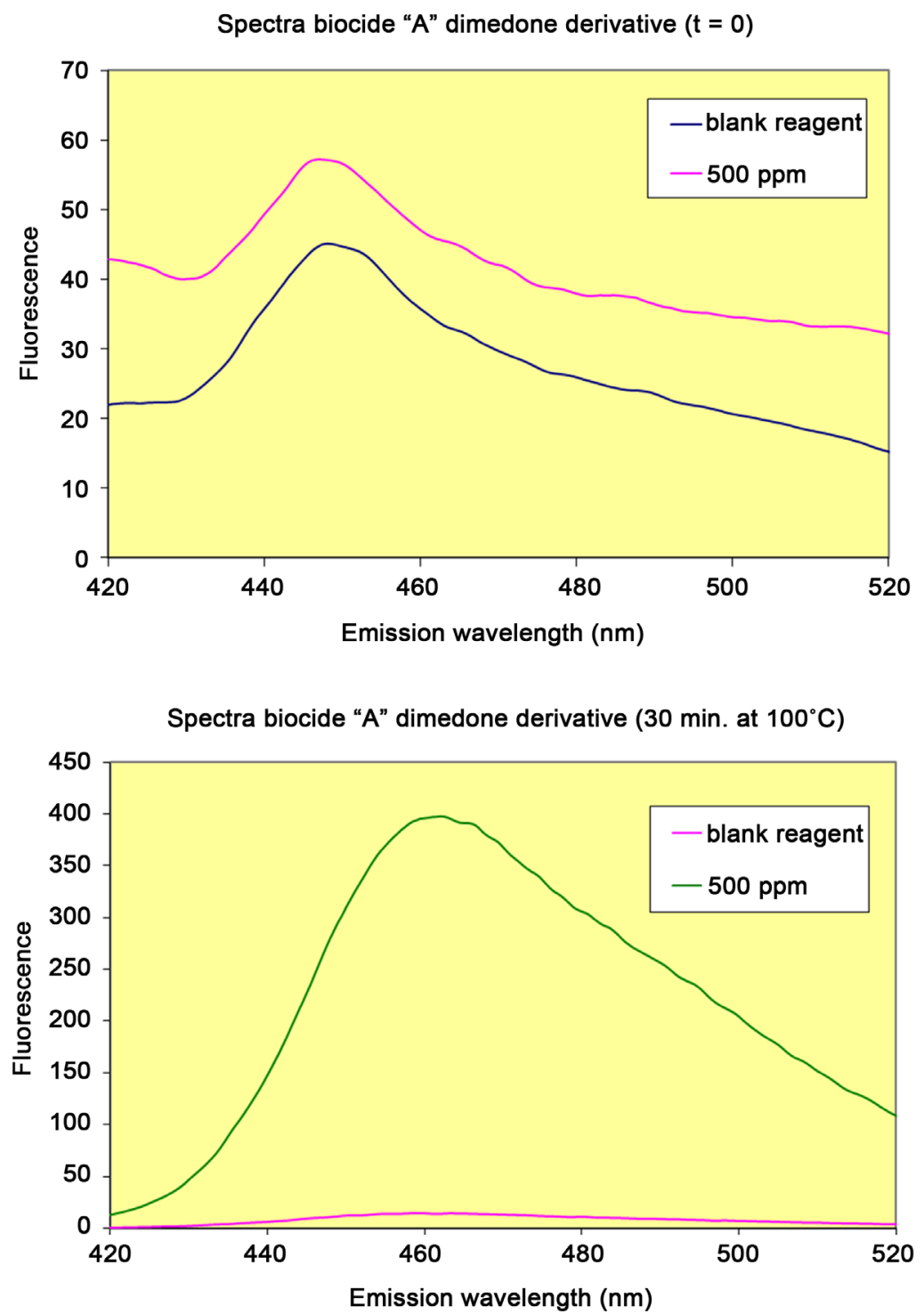

Figure 3. Emission spectra for the detection of aldehyde functionalities in seawater containing biocide A utilizing the dimedone assay.

tion are shown in Figure 4. The calibration curves showed that all four biocide formulations could be measured with high sensitivity and accuracy at relevant concentrations in seawater matrix. The assay setup is simple, robust and straightforward. The assay is therefore suited to develop into an on-line biocide sensor.

Next, the robustness and ruggedness of this promising assay was tested by means of a structural variation of the experimental parameters.

\subsection{Ruggedness of the Dimedone Assay}

The ruggedness or the susceptibility to interference of the dimedone assay was tested by introducing changes in the analytical parameters, according to the method for a ruggedness test described by Youden and Steiner as following. 

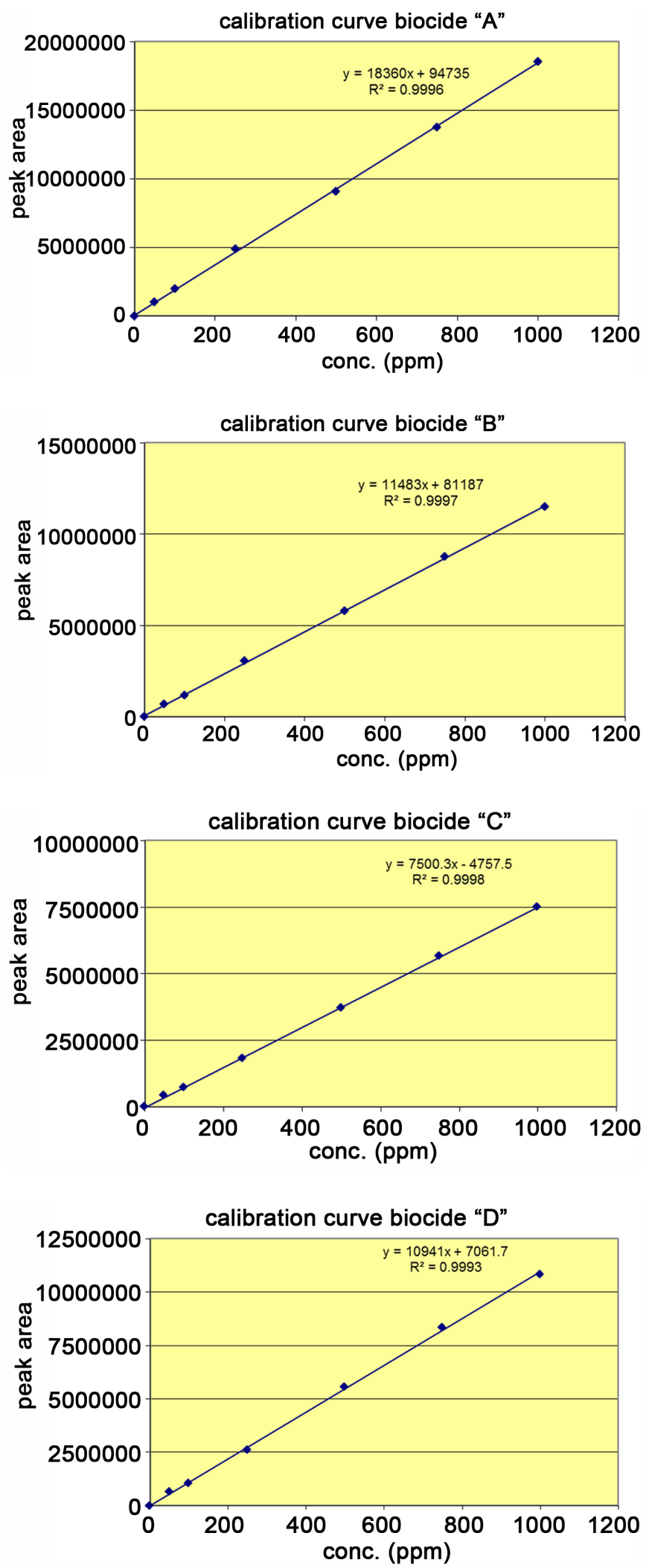

Figure 4. Calibration curves for the detection of aldehyde functionalities of the four different biocide formulations in a seawater matrix utilizing the dimedone assay. 
" $A$ ruggedness test is performed to establish whether an analytical method is sensitive to minor changes of various specific conditions of the method. The changes should be small and with a magnitude corresponding to what a chemist would expect to find among laboratories. The main objective of a ruggedness test is to identify conditions that must be carefully controlled and to discover those circumstances for which special care is needed. The ruggedness test is carried out by deliberately varying several parameters which are suspected to have a significant effect on the result. To achieve this, a set of multifactorial experiments must be designed for varying up to 7 factors simultaneously" [12].

The method as described above was repeated seven times, varying seven different parameters according to the matrix (Table 2). The $7^{\text {th }}$ variation was a dummy, as all possible variations were covered with six parameters and the method needed seven different parameters, according to the literature [12]. The measurement results in Table 2 were obtained by introducing the deviations according to the list in Table 3 .

All deviations from the ruggedness test (see column "Deviation" in Table 2) were well below the repeatability value of the method $(P<0.05)$. Therefore, it is concluded that the dimedone method is rugged.

\subsection{Application of Dimedone Assay for Mixed Biocide Formulations}

Further to the ruggedness test, the dimedone assay was tested for robustness with respect to mixing of the four different biocide formulations. This test was performed in order to be able to predict the results due to possible blending of the biocides by third parties.

The dimedone assay was performed on the individual biocide formulations and on a 1:1 mixture of the relevant pair of formulations, i.e. the two formulations "A and B" were mixed and the two formulations " $\mathrm{C}$ and $\mathrm{D}$ " were mixed. The measured response of the formulations and the mixtures was back calculated based on a calibration curve for formaldehyde. The results are summarized in Table 4.

Table 2. Parameter matrix and results of ruggedness test of dimedone assay.

\begin{tabular}{|c|c|c|c|c|c|c|c|c|c|c|}
\hline & \multirow{2}{*}{ Parameter } & \multicolumn{8}{|c|}{ Experiment } & \multirow{2}{*}{ Deviation } \\
\hline & & 1 & 2 & 3 & 4 & 5 & 6 & 7 & 8 & \\
\hline A & $\begin{array}{l}\text { Biocide diluted } \\
\text { with demi water }\end{array}$ & + & + & + & + & - & - & - & - & -0.0406 \\
\hline B & $\mathrm{Ex} / \mathrm{Em} 390 / 460 \mathrm{~nm}$ & + & + & - & - & + & + & - & - & 0.2954 \\
\hline $\mathrm{C}$ & Injection vol. $5 \mu \mathrm{l}$ & + & - & + & - & + & - & + & - & 0.0529 \\
\hline $\mathrm{D}$ & Eluent flow rate $1 \mathrm{ml} / \mathrm{min}$ & + & + & - & - & - & - & + & + & -0.1313 \\
\hline $\mathrm{E}$ & Reagent flow rate $0.5 \mathrm{ml} / \mathrm{min}$ & + & - & + & - & - & + & - & + & 0.3679 \\
\hline $\mathrm{F}$ & Reaction temp $100^{\circ} \mathrm{C}$ & + & - & - & + & + & - & - & + & 0.2972 \\
\hline \multirow[t]{2}{*}{ G } & Dummy & + & - & - & + & - & + & + & - & 0.0433 \\
\hline & Result & 12.3 & 11.54 & 11.8 & 11.72 & 12.06 & 12.13 & 11.38 & 11.95 & \\
\hline
\end{tabular}

+: according to method; -: deviation from method; Relative standard deviation $(\mathrm{RSD})=0.3092$; Repeatability $=$ $0.8749(P<0.05)$. 
Table 3. Deviation list used in the ruggedness test of dimedone assay.

\begin{tabular}{c}
\hline Deviation \\
\hline Dilution with seawater \\
Ex/Em $385 / 460 \mathrm{~nm}$ \\
Injection vol. $6 \mu \mathrm{l}$ \\
Eluent flow rate $1.1 \mathrm{ml} / \mathrm{min}$. \\
Reagent flow rate $0.6 \mathrm{ml} / \mathrm{min}$. \\
Reaction temperature $100^{\circ} \mathrm{C}$ \\
(Dummy) \\
Concentration of standard: $0.0148 \%$ formaldehyde \\
Dilution of biocide: 800 times.
\end{tabular}

Table 4. Measurement results of mixed biocide formulations using dimedone assay.

\begin{tabular}{ccccc}
\hline Parts “A” & Parts “B”* & Response $\left(\right.$ peak area $\left.\times 10^{6}\right)$ & \% formaldehyde in biocide ${ }^{\star *}$ & Theoretical value \\
\hline 50 & 0 & 7.35 & 11.23 & - \\
0 & 50 & 4.46 & 6.92 & - \\
25 & 25 & 5.39 & 8.3 & 9.08 \\
\hline Parts "C"* & Parts "D"* & Response (peak area $\times 10^{6}$ ) & \% formaldehyde in biocide & Theoretical value \\
\hline 50 & 0 & 1.9 & 3.08 & - \\
0 & 50 & 3.77 & 5.88 & - \\
25 & 25 & 2.99 & 4.72 & 4.48 \\
\hline
\end{tabular}

${ }^{*}$ In 1000 parts sea water. ${ }^{*}$ Back calculated based on calibration curve for formaldehyde.

The results showed that 1:1 mixing of the biocides coming from the same manufacturer led to an assay response that was nicely predicted by the theoretical value of the respective formulation.

\section{Conclusion}

This study described the development and performance of a biocide measurement assay based on the detection of aldehyde functionalities. The dimedone-based assay forms a fluorescent product as a function of aldehyde concentration in the biocide dissolved in a seawater mixture. The dimedone assay was proved to be a very promising assay for biocide measurement in seawater. The results of the ruggedness test also proved the suitability of the dimedone assay for development of an on-line biocide monitoring technique to detect the presence of a biocide slug in a seawater flooding system. Work is now in progress to develop the technology further in order to arrive at an automated on-line biocide sensor.

\section{Acknowledgements}

The authors would like to acknowledge the Saudi Arabian Oil Company (Saudi Aramco) for granting permission to publish this paper. 


\section{References}

[1] Al-Moniee, M.A., Al-Abeedi, F.N., Koopal, C., Akmal, N., Sanders, P.F. and van Veen, S. (2013) Development of Detection Techniques for Monitoring and Optimizing Biocide Dosing in Seawater Flooding Systems. International Petroleum Technology Conference, Beijing, 26-28 March 2013, 1-13. http://dx.doi.org/10.2523/IPTC-16978-Abstract

[2] Boivin, J. (1995) Oil Industry Biocides, NACE Canadian Western Region Conference, Calgary, Alberta. Reprinted in Materials Performance, 34, 65-68.

[3] Stewart, P.S., Hamilton, M.A., Goldstein, R.B. and Schneider, B.T. (1996) Modelling Biocide Action against Biofilms. Biotechnology and Bioengineering, 49, 445-455. http://dx.doi.org/10.1002/(SICI)1097-0290(19960220)49:4<445::AID-BIT12>3.0.CO;2-9

[4] Turner, A.P.E., Karube, I. and Wilson, G.S., Eds. (1992) Biosensors: Fundamentals and Applications. Mir Publishers, Moscow.

[5] Darsanaki, R.K., Azizzadeh, A., Nourbakhsh, M., Raeisi, G. and Aliabadi, M.A. (2013) Biosensors: Functions and Applications. Journal of Biology and Today's World, 2, 53-61.

[6] Tran, M.C. (1993) Biosensors. Chapman and Hall, London.

[7] Mulchandani, A. and Rogers, K.R., Eds. (1998) Enzyme and Microbial Biosensors: Techniques and Protocols. Humana Press, Totowa, NJ.

[8] Koopal, C.G.J. (2009) Development of an On-Line Biocide Detection System. Phase I: Feasibility Study. TNO Report V8267, TNO, Zeist.

[9] Saitoh, T., Suzuki, S. and Hiraide, M. (2006) Polymer-Mediated Extraction of the Fluorescent Compounds Derived by Hantzsch Reaction with Dimedone for the Sensitive Determination of Aliphatic Aldehydes in Air. Journal of Chromatography, 1134, 38-44.

http://dx.doi.org/10.1016/j.chroma.2006.09.002

[10] Sakai, T., Tanaka, S., Teshima, N., Yasuda, S. and Ura, N. (2002) Fluorimetric Flow Injection Analysis of Trace Amount of Formaldehyde in Environmental Atmosphere with 5,5Dimethylcyclohexane-1,3-Dione. Talanta, 58, 1271-1278.

http://dx.doi.org/10.1016/S0039-9140(02)00200-X

[11] Stahovec, W.L. and Mopper, K. (1984) Trace Analysis of Aldehydes by Pre-Column Fluorigenic Labeling with 1,3-Cyclohexanedione and Reversed-Phase High-Performance Liquid Chromatography. Journal of Chromatography, 298, 399-406. http://dx.doi.org/10.1016/S0021-9673(01)92737-2

[12] Youden, W.J. and Steiner, E.H. (1975) Statistical Manual of the Association of Official Analytical Chemists. Association of Official Chemists, Washington DC. 
Submit or recommend next manuscript to SCIRP and we will provide best service for you:

Accepting pre-submission inquiries through Email, Facebook, LinkedIn, Twitter, etc.

A wide selection of journals (inclusive of 9 subjects, more than 200 journals)

Providing 24-hour high-quality service

User-friendly online submission system

Fair and swift peer-review system

Efficient typesetting and proofreading procedure

Display of the result of downloads and visits, as well as the number of cited articles

Maximum dissemination of your research work

Submit your manuscript at: http://papersubmission.scirp.org/

Or contact jst@scirp.org 